\title{
Analytical Study of Archaeological Bricks from Coptic Period, Dayr AL-Naqlun (The Monastery of the Angel Ghubriyal), Fayoum, Egypt.
}

\author{
Abdel Rahim. Nagwa. $S^{1}$ \\ ${ }^{1}$ (Department of Conservation/ Faculty of Archaeology, Fayoum University, Egypt)
}

\begin{abstract}
The present paper describes the analytical study performed on three different sets of mud bricks from Dayr Al-Naqlun (The Monastery Of The Angel Ghubriyal) (Fayoum, Egypt) which dates back to the third century $A D$. The Bricks were made up according to a distinguished local school of Brick making which is known in Egypt from pre dynastic period. The materials used for the manufacture of the Bricks were revealed using $X$ ray diffraction $(X R D)$ and scanning electron microscopy-energy dispersive $X$-ray spectroscopy. The research had been studying two types of bricks, the first is Mud brick, which is characterized by the presence of some plant residues and many of compounds that are similar to the basic clay while the second type of baked brick, which is known (agar), (SEM-EDS) was revealed that the Bricks were made of ferruginous, highly calcareous clay in an oxidizing atmosphere. Mineral phases such as; Quartz, Hematite, Lime and feldspars have been identified which depended on the way of drying and firing degrees. Also a group of metallic materials such as quartz and impurities such as sulphate and carbonate.
\end{abstract}

Keywords: Egypt, Dayr Al- Naqlun, Coptic period, Bricks, mineralogical analysis, SEM-EDS, processing techniques

\section{Introduction}

Soil was used for buildings in Egypt before the making of mud bricks was developed. The Clay minerals are an integral part of earthen building materials. Forming the smallest grain size portion of this material, they also have specific mineralogical and physical properties that make them different from other common natural minerals. For this reason it is important to look further into their specific mineralogical character and their geologic origin, physical properties of clay minerals that are most important for earthen materials. [1]

The structural formula for kaolinite is $\mathrm{Al}_{4} \mathrm{Si}_{4} \mathrm{O}_{10}(\mathrm{OH}) 8$ and the theoretical chemical composition is $\mathrm{SiO}_{2}, 46.54 \% ; \mathrm{Al}_{2} \mathrm{O}_{3}, 39.50 \%$; and $\mathrm{H}_{2} \mathrm{O}, 13.96 \%$. The major smectite minerals are sodium montmorillonite, calcium montmorillonite, saponite (magnesium montmorillonite), nontronite (iron montmorillonite), hectorite (lithium montmorillonite), and beidellite (aluminum montmorillonite). Smectite minerals are composed of two Quartz tetrahedral sheets with a central octahedral sheet and are designated as a 2:1 layer mineral. Water molecules and cations occupy the space between the 2:1 layers.

The physical and chemical properties of a particular clay mineral are dependent on its structure and composition. The structure and composition of the major industrial clays, i.e. Kaolin, smectites, and palygorskite-sepiolite, is very different, even though each is comprised of octahedral and tetrahedral sheets as their basic building blocks. However, the arrangement and composition of the octahedral and tetrahedral sheets account for most differences in their physical and chemical properties. [2]

Kaolin is both a rock term and a mineral term. As a rock term, kaolin means that the rock is comprised predominantly of kaolinite and/or one of the other kaolin minerals. As a mineral term, it is the group name for the mineral kaolinite, dickite, nacrite, and halloysite. Kaolinite is by far the most common kaolin mineral. Dickite, nacrite, and halloysite are relatively rare in comparison. These latter three minerals are commonly formed by hydrothermal alteration, although there are examples of their occurrence in sedimentary and residual deposits in association with kaolinite. Common clays can be seated earths (underclays), shales, lacustrine clays, soils, and other clay-rich materials.[3]. Usually, the clay mineral composition of these materials is mixed. For example, shale commonly contains illite, chlorite, and mixed-layer illite-smectite or illite-chloride. Mixedlayered or interstratified clay minerals usually contain two components such as illite and smectite. Most commonly, the layers are randomly ordered, but can be regularly ordered. This regularly ordered illite-smectite is called rectories.[4]

The physical and chemical properties are very diverse, so these common clays are utilized for specific end uses. The physical properties that are normally important relate to their use in the manufacture of structural clay products such as bricks and tiles. These properties are plasticity, green strength, dry strength, dry and fired 
shrinkage, fired colour, fired strength, vitrification range, and fired density. Many shales and seat earths (underclays) are suitable for making structural clay products.[5]

When in their normal use as a building material bricks, as artifacts, are open to systematic recording by archaeologists. They have put forward as a set of standard headings under which brick details should be routinely recorded, The composition of the bricks, and whether burned or unburned The dimension of the bricks. The bonding, preferably described by means of a corpus of bonds. The distribution of any reed-matting or timber tie beams in the brickwork. The nature of the mortar. Details of any plaster, whether stamped bricks occur, any special usages, or bricks of special form. [6]

The ancient Egyptian used the clay as material helping in the construction, including mud brick and agar, the construction of walls. There are two types of bricks used in building: -

\section{1.Mud Bricks:}

Ancient Egyptian have used mud-brick since the pre-dynastic period. Although (mud bricks ) is the term most often used in Egyptology,: Adobe "has a more widespread currency.

They were found in Naqada in Upper Egypt, in the tombs at Abydos and Saqqara, in Abydos were made bricks from the River Nile clay deposits of silt which is a mixture of the clay and sand with a percentage of the primary minerals, iron oxides and organic materials, which composition depend on the location from Aswan to Alexandria, and the seasons. Using with specific dimensions varies widely wooden moulds and almost equal in proportions with the modern brick while others are very large, where the Egyptian Museum keeps two samples of dimensions $(96.5 \times 53.3 \times 30.5 \mathrm{~cm})$ and is still the same method used so far as leaving blocks of dry warm air away from direct sun t. The advantage of this method is as easy does not require effort or experience in their preparation with their licenses as well as thermal insulation in summer and winter so it has ancient Egyptian virtues in buildings mundane intense atmosphere in Egypt for suitability so equal in the public building houses with nobles and Pharaohs so it is not found on the cities or neighbourhoods Full of these ages because the bricks are less likely than the stone of the weather conditions.[6]

\subsection{Burned bricks (Agar):}

The mud brick and the agar have the same methods of manufacture and components but the agar burn in high temperature .The mud brick kilns had burned at temperatures between $500-700^{\circ} \mathrm{C}$ such as pottery turns into the reddish brick .Egyptian makers used it since ancient times, but the red brick has not been preferred in Egypt before the Roman era in spite of its role in other nations as well as multiple different forms for bricks currently used and there are two types: the small brick and the large brick have been used in multiple situations, including modern Ahnasia (Bany Suef), Kom Al shoqava (Alexandria).[6]

Presents a critical point in the process of brick, a brick industry segment where gaining solidity and permanence and are producing the temperature gradually and slowly until all the water evaporates. Then elevate the temperature to the desired limit for the production of pottery, and the final stage of the burning phase out the water Chemically adsorbed or combined water, and turns the mud from his first fragile where water effects to the solid state does not affect the water where the oven temperature be between $\left(500-600{ }^{\circ} \mathrm{m}\right)$, in which the metal Alcaullent (aluminium Quartzte) to the material, amorphous-like glass when these degrees turns from the heat and back again to the case of crystallization only when high degrees about $1000^{\circ} \mathrm{m}$ The Anthrasthaddam severity of mud-brick and burned (agar) in all buildings architecture Coptic result of the presence of the Nile silt was also used in some places as in Deir Mansuriya .

The properties of the clay differ from one case to another according to the difference in chemical makeup; this greatly affects the point of inflammation. The mud used in Egypt in manufacturing the bricks had two types: one of them is the clay which holds back a heavy capacity of constitutional issues, iron elements and crystal.It exists in delta and Nile valley. The other case which incorporates organic materials, calcium components exists in Kenya and Balas in Upper Egypt. Likewise, water significantly affects the characteristics of the clay used [7]. The division between clays is now so well-established in Egyptian archaeology that attempting to convert it would be counterproductive. The clays are size terms, for particles respectively 0.06 $0.002 \mathrm{~mm}$ and $<0.002 \mathrm{~mm}$ in diameter. The technology of pottery making has gained attention in terms of methods of shaping varying between the simple manual shaping and the use of a sheet, or moulds [8]. Temperature of $1000^{\circ} \mathrm{C}$ can be made relatively easily with a simple up draught kiln, and the examination of Egyptian pottery by various re-firing techniques suggests that most firing temperatures were considerably below this temperature. They establish a mean maximum temperature for open firing of $860^{\circ} \mathrm{C}$ as high as $900^{\circ} \mathrm{C}$ but over $600^{\circ} \mathrm{C}$ are mostly sufficient to sinter clay and render it ceramic [9]. The deterioration factors of ancients Bricks are divided into two sections. The Intern al factors involve inhomogeneous in physical attributes between the mineral and non-mineral contents in its construction, its crystalline forms and its coherence. They likewise include the manufacture faults done by the manufacturer or occurrence as a consequence of an external 
condition during the fabrication operation. The external factor includes physical and chemical factors, the effects of high temperature, humidity, air pollution, ground water, which carries salts and also biological deterioration. [10]

\subsection{The Dayr Al-Naqlun}

\section{Headings}

This paper discusses the Coptic monuments from cemetery C at Deir al-Naqlun in Egypt $\left(29^{\circ} 11^{\prime} 35^{\prime \prime} \mathrm{N}\right.$ $30^{\circ} 52^{\prime} 31^{\prime \prime E}$ ). The site is also known in the literature as Deir el-Malak Ghubriel (Monastery of Archangel Gabriel). It is located in the Western Desert, at the base of a rocky cliff, 16 kilometers south of the city of foam and $120 \mathrm{~km}$ from Cairo. It is one of the oldest, still existing Coptic monasteries in Egypt, with its roots reaching into the 6 th/7th or even the 5th century CE. Excavations at the site have been carried out since 1986 by the Institute of Archaeology, University of Warsaw team led by Włodzimierz Godlewski. (Dobrowolski 1990). [11]

\subsection{Topographical Survey}

More importantly, this new topographical survey provided an opportunity to revamp the original archaeological nomenclature which had lost its original clarity in the wake of intensive development of the modern monastery. The new designations of the dissimilar sections of the archaeological site are as follows:

1) The Eastern group of hermitages situated in the valleys and hollows of Gebel Naqlun, altogether 81 identified rock-cut complexes; the figure may even rise.

2) The Western group of hermitages located near the canal, eight complexes at present; three of these are dated to the middle and second half of the 5th C.[12]

3) Cemeteries C.1 and C.2, dated to the final stage of the 5th and the 6th century, currently west of the monastery enclosure wall opposite the west gate.

4) Site A (main cam) to the east of the later medieval monastery, including monastic architecture from the end of the 5th and the 6th century, as well as later structures dated to the 10th and 11th century when AlNaqlun monastery reached a peak in development. In the second half of the 11th and in the 12th century, an extensive cemetery grew around the Church of the Archangel Michael on Site.It was yet in use in the 13th C..

5) Church of the Archangel Gabriel, erected in the 8th century and refurbished at the start of the 11th century, encompassing a partly preserved complex of medieval architecture. [13],[14],[15],[16]

(Dobrowolski 1990).

The complex was fenced in by walls and accessible through a still existing western gate. It was altered in modern times and refurbished in the 20th C. This monastery consists of the two Churches Figure 1. Shows General view of the monastery and is surrounded by a wall built of stone, mud brick and burned brick(agar), and is adjacent to the monastery excavation area carried out by the Polish mission in this region for several seasons has been detected through which many of the holdings had its own set of brick tombs were built with bricks, it was found by the bodies of the martyrs of Fayoum, and the remains of the walls of the church planning Basilkih made of mud brick, and is adjacent to the church three rooms and by him, and was probably the residential building. Figure 2. Shows the design of the two Churches of the monastery. [14].

\subsection{Samples and Sample preparation}

\section{Indentations and Equations}

The selected samples were chosen from different places of the monastery to study, All the Samples are very small, Figures (3 .1-7) Show the samples location in Deir al-Naqlun and they are installed as follows: -

3.1.1. The first sample: -mud-brick of the outer wall of Dayr Al-Naqlun as shown in the figure (3-1).

3.1.2. The second sample: -the brick from the wall of Dayr Al as shown in the figure (3-2).

3.1.3. The third sample: -brick wall of the monastery as shown in the figure (3-3).

3.1.4. The fourth sample: -the agar brick of the contract is located in the wall of a corridor leads to the Michael Church as shown in the figure (3-4).

3.1.5. The fifth sample: -agar-brick wall of another corridor leads to the Michael Church as shown in the figure (3-5).

3.1.6. The sixth sample: -mud brick of the contract is located in Dayr Al- Gabriel's Church as shown in the figure (3-6).

3.1.7. The seventh sample: - the agar brick from a square in the wall located on the right northern porch of the Church of Dayr Al-Malak Ghubriyal as shown in the figure (3-7).

\section{2 .X-rays Powder Diffraction (XRD)}

Preliminary analysis by X-ray powder diffraction (XRD) allowed the identification of major crystalline phases in the ceramic body. XRD was performed with an X'Pert PRO PANalytical diffractometer equipped with 
conventional X-ray tube $(\mathrm{Cu}-\mathrm{K} \alpha)$ radiation $(\mathrm{k}=1.5406 \AA)$ with power condition $45 \mathrm{KV}$ and $40 \mathrm{MA}$. The XRD patterns were measured in the range of 4 to $70^{\circ}(2 \theta)$ with the step size of $0.02^{\circ}$ and $30 \mathrm{~s}$ counting per step at room temperature $\left(25^{\circ} \mathrm{C}\right)$.

\subsection{Scanning Electron Microscopy- Energy Dispersive X-Ray Spectroscopy (SEM-EDX)}

The SEM-EDX was used to determine microtextural and microchemical features of the physical structure. ESEM microscope (model Philips XL 30 ESEM) supported by a semi - quantitative (EDX) unit was applied for mineralogical investigations. The analytical conditions are $25-30 \mathrm{kv}$ accelerating voltages, $1-2 \mathrm{~mm}$ beam diameter and $60-120$ second counting times. Minimum detectable weight concentration from 0.1 to 1 wt $\%$. Precision well below $1 \%$, the relative accuracy of quantitative result $2-10 \%$ for elements $\mathrm{Z}>9(\mathrm{~F})$, and 10 $-20 \%$ for the light elements B, C, N, O and F. All analyses were carried out at the laboratories of the Nuclear Materials Authority (NMA), Cairo, Egypt.

\subsection{The XRD analysis}

\section{Results and Discussion}

The results indicate that this clay has the presence of a high proportion of Quartz in the form of either filler or as a part of the composition of a metal. Quartz $\left(\mathrm{SiO}_{2}\right)$, one of the most important minerals is a pure Quartz and metal acts in some objects as an aid to fusion, but in the case of the studied agar samples it is a thermal material where Quartz starts melting at $1600{ }^{\circ} \mathrm{C}$ and completes melting at $1780{ }^{\circ} \mathrm{C}$ [19]. Trydimite $\left(\mathrm{SiO}_{2}\right)$, It is also a form of Quartz, when burning the clay contains a high proportion of Quartz quartz to become Trydimite at temperatures between $780,1470{ }^{\circ} \mathrm{C}$, resulting in a renewed and rearrangement crystallization. This transformation is not irreversible. Anorthite $\left(\mathrm{CaAl}_{2} \mathrm{Si}_{2} \mathrm{O}_{8}\right)$ Hematite $\left(\mathrm{Fe}_{2} \mathrm{O}_{3}\right)$ and Magnetite $\left(\mathrm{Fe}_{3} \mathrm{O}_{4}\right) \mathrm{High}$ proportion of red iron oxides is attributed to reddish brown colour of the pottery.. Also a group of metallic materials such as quartz and impurities such as sulphate and dolomite are present [20].

\subsection{SEM-EDX}

Using the Scanning Electron Microscope, the internal structuring composition of the fabric of bricks could be determined, it is Homogeneity, The body is ferruginous [16] with Hematite content $\left(\alpha-\mathrm{Fe}_{2} \mathrm{O}_{3}\right)(5.90 \%)$ which is responsible for the red colour of the body. In terms of calcium content, the body is made of highly calcareous clay in which Ca content (16.08\%). Quartz content is $(27.06 \%)$, alumina (8.68\%), and Alkali content $\mathrm{Na}_{2} \mathrm{O}(0.68 \%), \mathrm{K}_{2} \mathrm{O}_{2} .(16 \%)$, and $\mathrm{MgO}(2.34 \%)$. The body contains coarse quartz grains surrounded by smaller sub-angular grains in addition to very fine quartz grains in the glassy matrix, it has same gaps.

Quartz is abundant in the enamel base (2-32\%) and the alkali revealed is mainly Barium BrO $(8.89 \%)$ which is much greater than sodium $(4.32 \%)$ and potassium $(2.06 \%)$, (which probably proceeding from wood ignition), are the main alkaline raw material.

Table1. Shows chemical composition of ceramic body and green glaze layer with EDX analysis

Figures (4-10) Show the body layer of the samples (a, b) SEM image, (c) EDX spectrum.

4.2.1. The first sample of mud-brick sample shows relatively few light- coloured harmonies and shows a clear some plant residues that have not been crushed well, as shown in figure (4) zooms $2000 \mathrm{X}$.

4.2.2. The second sample of brick bricks relative homogeneity between components appears with the absence of some plant remains as indicated in figure (5) zooms $2000 \mathrm{X}$

4.2.3. The third sample brick, brick seems partial coherence between components with no plant residue This is evidence of a good grinding him as depicted in figure (6) zooms in3500 X.

We note the presence of bacteria between the components of the bricks which was a spherical bacteria [21].

4.2.4. The fourth sample piece of brick and it seems clear semi-homogeneity between the components with the bonding between grains crystallized, as shown in figure (7) zooms $2000 \mathrm{X}$.

4.2.5. 4.2.5 The fifth sample of mud- brick appears in the form semi-coherent granules and shows some consistency with the presence of some plant residue milled well as shown in figure (8) zooms $1000 \mathrm{X}$.

4.2.6. The sixth sample of bricks shows extreme heterogeneity of its components with the absence of any plant residue as shown in figure (9) zooms 3500X.

4.2.7. The seventh sample of brick bricks relative homogeneity shows with some blanks as a result of lack of good kneading as well as the lack of good pressing of components within the template used in the formation of the bricks as shown in figure (10) zooms $2000 \mathrm{X}$.

Through the results of the analysis, we found that silicon is the main component of the samples, calcium, iron, aluminum and potassium with small percentages of copper, titanium, sulphur, lead and chlorine. And have led collecting and recording the results of the analysis in table (1). It contains the results of the analysis of the seven samples by X-ray scattering shows where the percentage of each element in the presence of each sample separately 
Figures and Tables

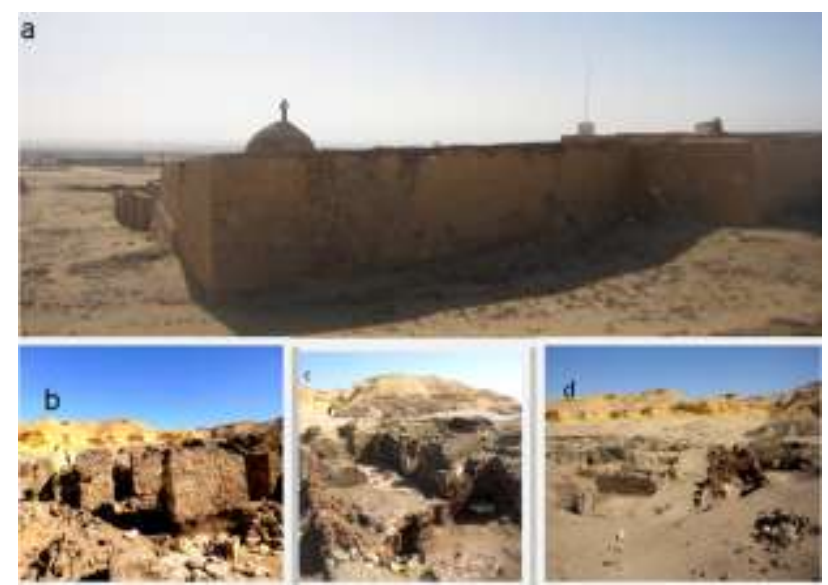

Figure (1) Shows (a) General view of Deir al-Naqlun , (b,c,d) , Excavation around Deir al-Naqlun

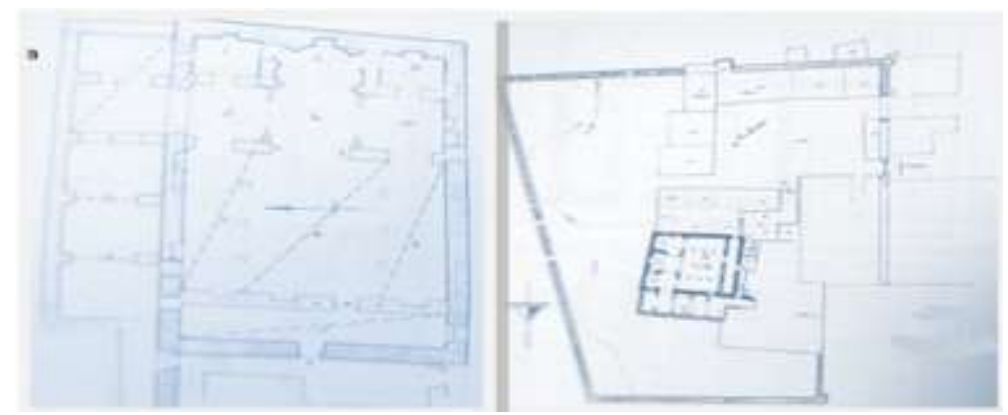

Figure ( 2 a, b) shows the design of the two churches at Deir al- Naqlun 

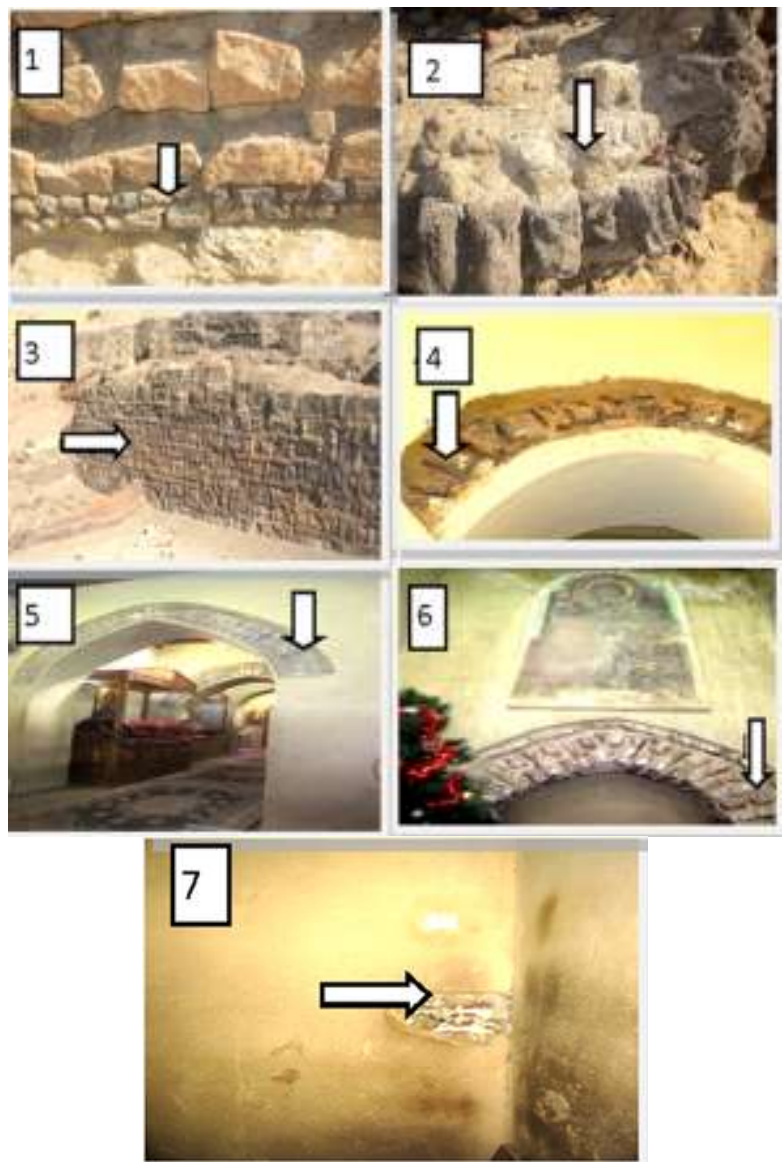

Figure (3.1-7) shows the samples location in Deiral-Naqlun.
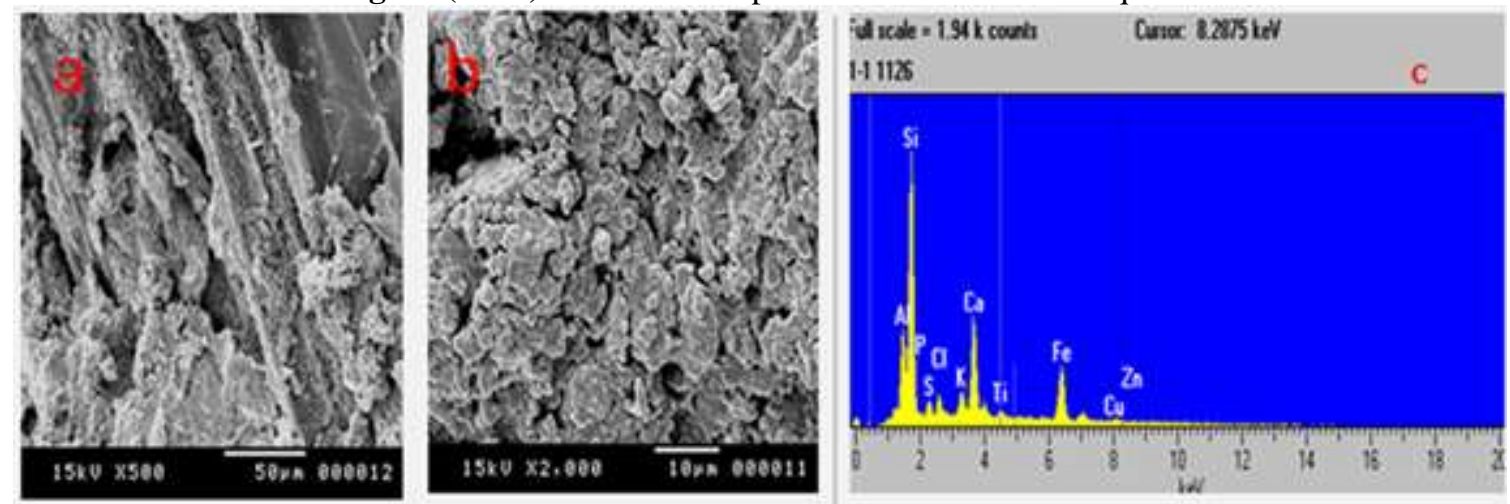

Figure (4) Shows the first sample (a, b) SEM image (c) EDX spectrum
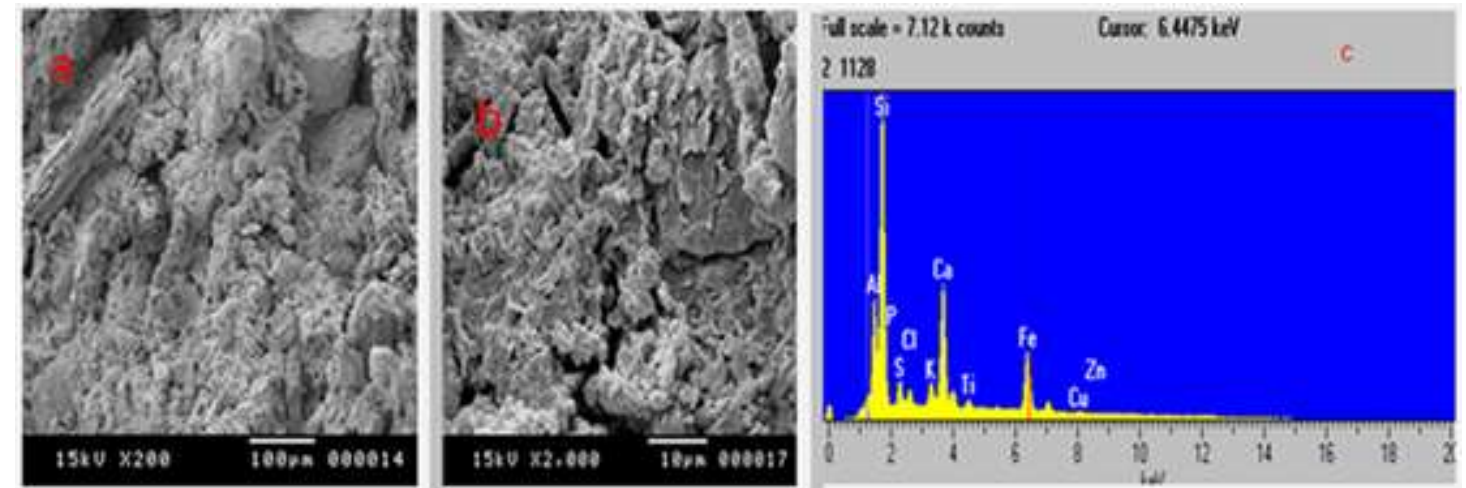

Figure (5) Shows the second sample (a, b) SEM image, (c) EDX spectrum. 

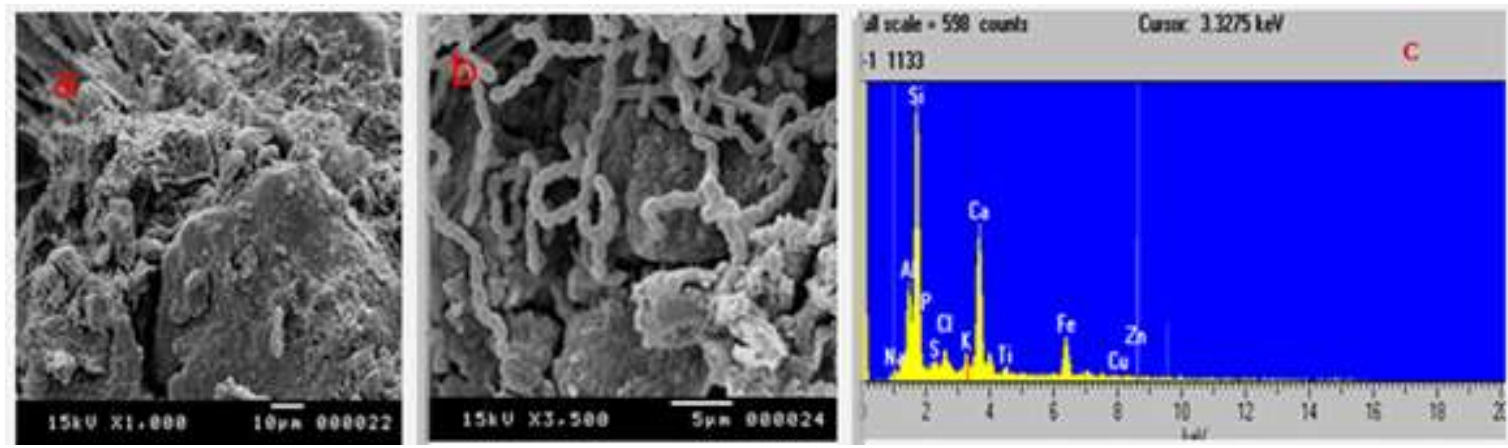

Figure (6) Shows the third sample (a,b) SEM image, (C) EDX spectrum

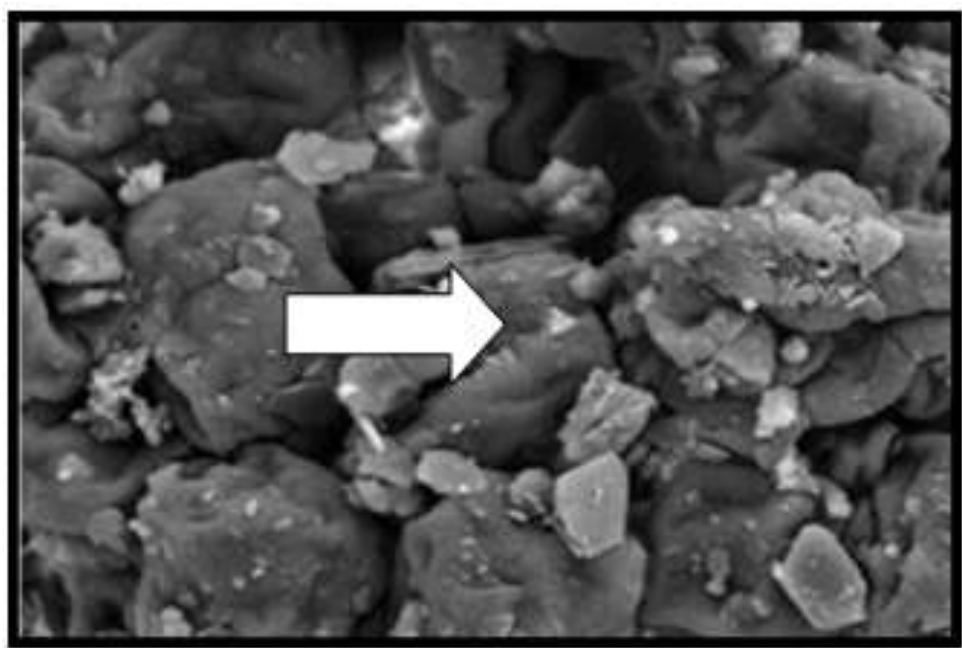

Figure (6a) Shows the type of bacteria
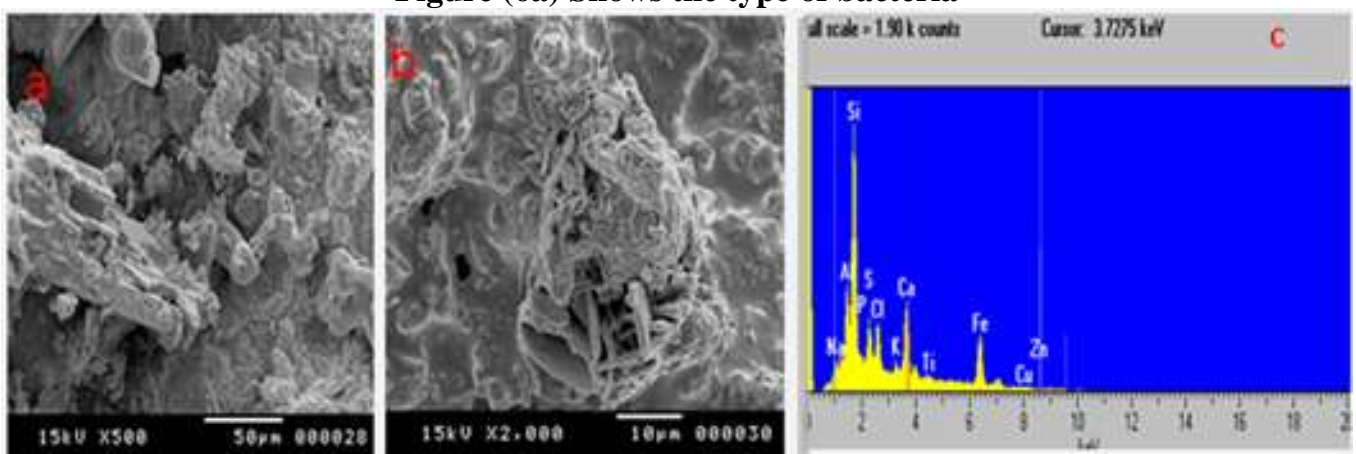

Figure (7) Shows the fourth sample (a,b) SEM image (c) EDX spectrum.
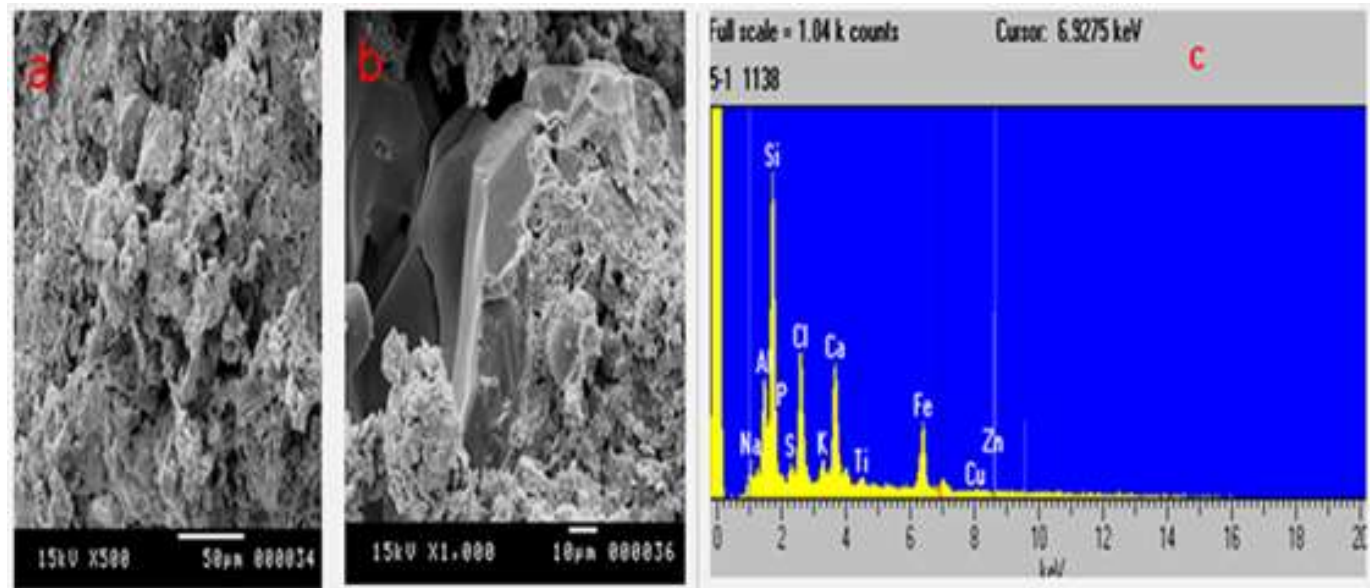

Figure (8) Shows the fifth sample (a, b) SEM image, (c) EDX spectrum. 

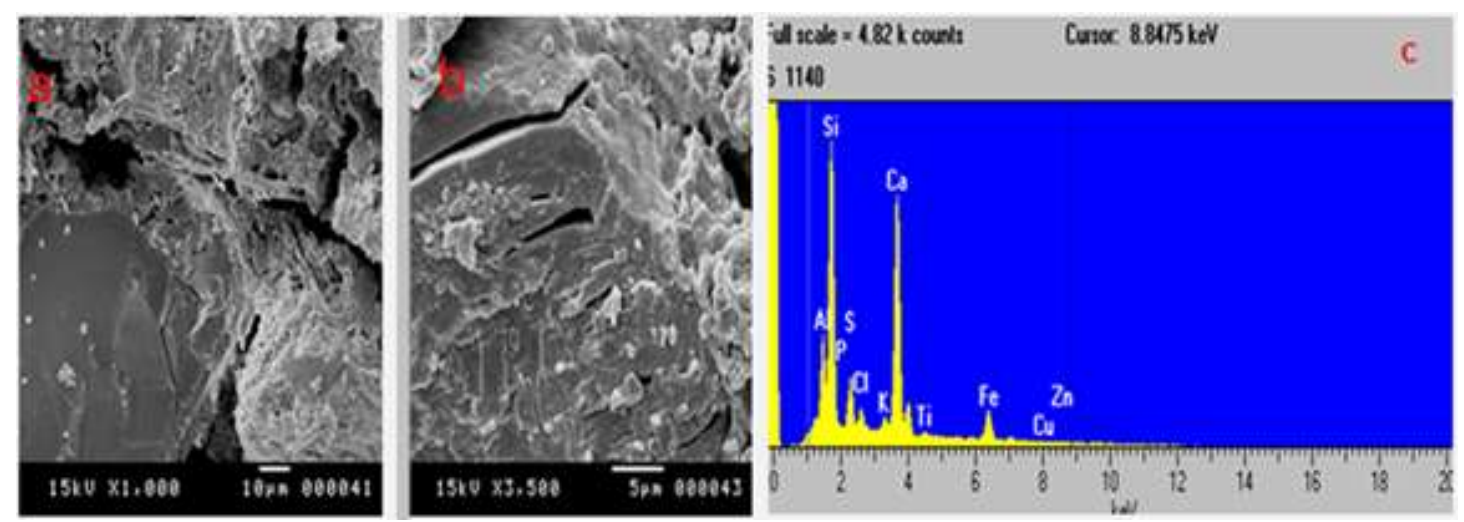

Figure (9) Shows the sixth sample (a, b) SEM image, (c) EDX spectrum.
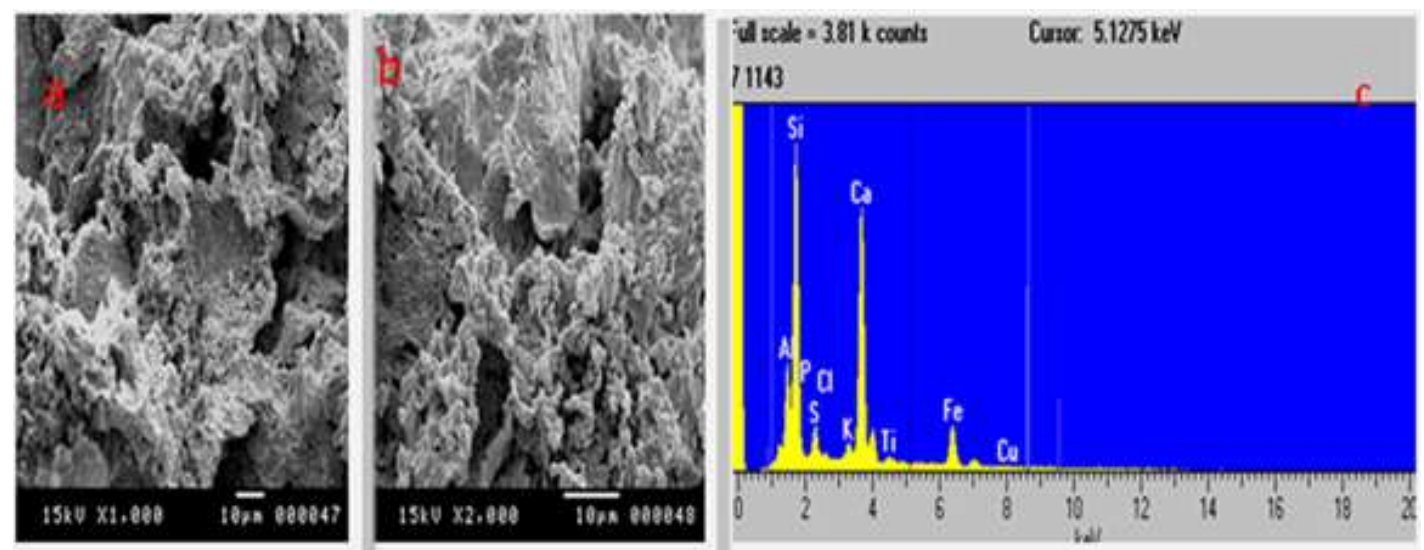

Figure (10) Shows the sixth sample (a, b) SEM image, (c) EDX spectrum.

Table1. Shows chemical composition of the samples with EDX analysis

\begin{tabular}{|c|c|c|c|c|c|c|c|}
\hline Elements & 1-wt \% & 2 -wt\% & 3-wt \% & $-4 w t \%$ & -5 WT $\%$ & $-6 w t \%$ & $-7 \mathrm{wt} \%$ \\
\hline Al & 6.39 & 4.72 & 5.01 & 4.47 & 4.56 & 3.16 & 3.56 \\
\hline $\mathrm{SiO2}$ & 20.92 & 19.96 & 19.72 & 17.70 & 16.96 & 17.94 & 19.25 \\
\hline $\mathbf{P}$ & 0.69 & 1.68 & 1.84 & 2.17 & 1.88 & 1.88 & 1.45 \\
\hline $\mathbf{S}$ & 1.17 & 3.32 & 0.46 & 3.16 & 0.62 & 3.42 & 1.92 \\
\hline $\mathrm{Cl}$ & 1.60 & 1.36 & 1.47 & 3.89 & 7.51 & 1.68 & 0.53 \\
\hline $\mathbf{K}$ & 2.24 & 2.23 & 1.90 & 1.04 & 1.81 & 1.85 & 2.02 \\
\hline $\mathrm{CaO}$ & 9.26 & 10.73 & 12.74 & 7.03 & 8.04 & 20.32 & 20.12 \\
\hline $\mathbf{T i}$ & 1.38 & 1.12 & 0.69 & 0.40 & 1.10 & 0.44 & 0.50 \\
\hline Fe2O3 & 13.02 & 10.61 & 9.24 & 11.13 & 11.02 & 6.05 & 8.33 \\
\hline $\mathrm{Cu}$ & 0.21 & 0.13 & 0.07 & 0.09 & 1.10 & 0.33 & 0.09 \\
\hline Zn & 0.21 & 0.02 & 0.44 & 0.56 & 0.73 & 0.53 & - \\
\hline $\mathbf{O}$ & 42.93 & 44.16 & 41.67 & 42.09 & 38.42 & 42.39 & 42.22 \\
\hline $\mathrm{Na}$ & - & - & 4.74 & 6.27 & 6.24 & - & - \\
\hline
\end{tabular}

\section{Conclusion}

This is an analytical study of the bricks dated to the Coptic period, which dates back to the third century AD. In region. Which is considered an important city in Egyptian history where it belongs to the city of Fayoum with a long history extending through different Egyptian ages, characterized by many religious buildings and industries, including pottery, glass, and bricks, The study was included two types of bricks used in the construction of the monastery they were mud brick and burned brick . In terms of the raw materials used, the use of X ray diffraction (XRD) helped in identification of the components of bricks through the crystalline compounds. In addition, it revealed the mineral changes occurred during burning the clay, which indicated the burning temperature of burned bricks that affects the crystal phases of metals in the clay during burning. From the minerals identified; Anorthite, Trydimite, magnetite, ferric oxide, potassium Quartzes, aluminum and Quartzite were found. In addition, quartz could be naturally found in the clay or deliberately added. From these revealed minerals, we conclude that all the bricks were made of Nile clay containing quartz, potassium Quartzes, aluminum Quartzite (Orthoclase) in addition to Trydimite which might be classified as one of the crystallized Quartz phases formed as a result of burning calcareous clay over $\left(780^{\circ} \mathrm{C}\right)$. Using the Scanning Electron Microscope, the internal structuring composition of the fabric of bricks could be determined. Some 
Homogeneity with the appearance of some gaps, plant debris and, the shape of grains in terms of coherence and fragmentation, and all these are the advantage of the bricks of the Nile Clay ,possible to identify the mineralogical composition of the studied bricks . The weaving of bricks, , the particles of old pottery, the grains of quartz quality grinding used in the preparation process, and less homogeneity in the tissue when preparing the clay. [19].

The petrographical and minera logical analyses and their ical data allowed not only the characterization of these bricks, but also the formulation of some hypotheses regarding their specific manufacturing techniques. Technology y, manufacture, materials used of the bricks located in Dayr Al-Naqlun region could be summarized as follows. The bricks any analyzed is found to be a domestic brick that were used in their daily life. It was also found that the texture of the bricks was made using Nile Clay fabric which is characterized with a large quantity of medium to coarse plant residues and high porosity which is suitable for manufacturing these types of bricks. The addition of some materials such as sand and pottery as arguments is to improve the moulds properties of the moulds, these materials are known as temper or fillers. The bricks were handmade shaping, and their colors vary between reddish to brown due to the presence of iron oxides mainly hematite and magnetite. $\bullet$ The presence of trydimite indicated that the firing temperature was above $780{ }^{\circ} \mathrm{C}$. And the hardness of the red bricks (agar) is medium.

The raw material components of the clay do not change much over time because it is a natural raw material.

\section{References}

[1]. Avrami, E, Guillaud, H, Hardy, M,. Terra Literature Review An Overview of Research in Earthen Architecture Conservation, Los Angeles, J. Paul Getty Trust, 2008,p,1.

[2]. Murray ,H, Applied Clay Mineralogy Occurrences, Processing and Application of Kaolins, Bentonites, PalygorskiteSepiolite, and Common Clays, Developments in Clay Science, 2, USA Elsevier, 2007, p21.

[3]. Murray, H.H. Common clay. Chapter in Industrial Minerals and Rocks, 6th Edition. Carr, D.D., Ed. Society for Mining, Metallurgy and Exploration, Littleton, CO, (1994) pp. 247-248

[4]. Moore, D.M. And Reynolds, R.C. Jr,X-Ray Diffraction and the Identification and Analysis of Clay Minerals, 2nd Edition. Oxford University Press, Oxford and New York, . (1997),p, 378.

[5]. Velde, B , Meunier, A,.( 2008), The Origin of Clay Minerals in Soils and Weathered Rocks Library of Congress , Springer ,Berlin Heidelberg, p. 69.

[6]. Nicholson, P. \& Shaw, I., (2000. Ancient Egyptian materials and technology, Cambridge Univ. Press, London. [6] Lucas, A, (1962) Ancient Egyptian Materials and Industries, Fourth Edition, London, pp. 18-20.

[7]. Lucas, A, (1962) Ancient Egyptian Materials and Industries, Fourth Edition, London, pp. 18-20.

[8]. Nicholson, P, T. Patterson, H, L, (1985) Pottery making in Upper Egypt, anethnoarchaeological study.WA, Vol. 17, p. 39.

[9]. Mattson, S, (2003) T he Complete Potter, Copyright, p.45.

[10]. Paice,P, (1989) T he Pottery of Dail y Life i n Ancient Egypt, The Journal of The Society for The Study of Egyptian Antiquities, JSSEA, vol. XIX, pp: 67-73.

[11]. Johnson J., (1998). Soluble salts and deterioration archaeological materials, Conserve O Gram No.6/5, National Park Services, Washington

[12]. Dobrowolski J. (1990), Naqlun - Deir Al-Malak Ghubrã 'il: The Existing Monastic Complex, Nubica 1/2:161-170.

[13]. Godlewski,W:-Naqlun ,Excavation1997,Polsh Archaeology In The Mediterranean IX ,polish center of Mediterranean Archaeology Warsaw University ,Reports1997, Warsaw ,1998,p,77.

[14]. Ożarek,M.A. Bioarchaeology of the Near East 2:99-103 (2008) Short Fieldwork Report: Deir a -Naqlun (Egypt), season 2006.

[15]. Derda, T. 1995 Deir el-Naqlun: The Greek Papyri (P. Naqlun I), Warsaw: Warsaw University Press Dobrowolski, J. 1990 Naqlun Deir al-Malak Ghubra'il: The Existing Monastic Complex, NubicaI/II, 161-170 Godlewski, W. 2005 Naqlun (Nekloni). Season 2004, PAM XVI [=Reports 2005], 181-190.

[16]. 2008 Naqlun 2007: Preliminary report, MISHKAH. Egyptian Journal of Islamic Archaeology 3, Cairo: Supreme Council of Antiquities, 65-77.

[17]. Godlewski, W., Czaja-Szewczak, B. 2009 Naqlun cemetery C.1: Tomb C.T.5 and its catalogs, PAM XVIII [=Reports 2006], 247260 .

[18]. Godlewski, W :- A mission of the Polish Centre of Mediterranean Archaeology of the University of Warsaw, directed by Prof. Włodzimierz Godlewski, 1 completed another season of excavations on the site of the Nekloni monastery in Fayum between 8 September and 22 October 2007.

[19]. Zych, I. 2009 Cemetery C in Naqlun. Preliminary report on the excavation in 2006, PAM XVIII [=Reports 2006], 230-246.

[20]. Reedy, C, L, (2007) Thin-Section P etrography of Stone an d C eram ic C ult ural Materials, London, p.141.

[21]. Nicholson, P. T, (2000) Ancient Egyptian Materials and Technology, London, p. 183.

[22]. Abd elmoaz,A,.Scientific study for consolidation of mural painting excuted by fresco technique by the biomineralization of bacteria, applied on one of selected objects, Ph.D. Conservation of Antiquities, Archaeology Conservation Department, Cairo University, 2014,p34. 